\title{
Google \& Apple’s Gale of Creative Destruction
}

\author{
Nigel Walton, Klaus Oestreicher \\ University of Worcester, Worcester, United Kingdom
}

\begin{abstract}
Creative destruction is an economic theory of innovation popularised by Austrian economist Joseph Schumpeter. In this paper, Schumpeter's theories are used to explain how radical technological innovations in information-intensive industries are influencing the erosion of traditional industry and market boundaries leading to the emergence of new competitive business models and strategies. Developments in digital technology has resulted in new technological shifts and market linkages resulting in dilemmas for the existing incumbents in traditional industries who find themselves increasingly trapped and victims of a new innovation logic. The new value innovation logic is being driven by entrepreneurs such as Page and Brin (Google) and Jobs (Apple) who are currently in the process of revolutionising the economic structures of many industries and creating new markets and organisational business models in a gale of creative destruction reminiscent of the theories developed by Sombart and Schumpeter. This creation of new market models and their impact on established industries are explained further in the value chain evolution theory and its corollary sustaining innovation classification-scheme. These theories reinforce the view that innovators, thinking in new and radical ways, provide sustainable new market developments and earn above the average revenues compared to incumbents, whose profit pools have eroded. This paper researches and analyses the impact that Google and Apple are having upon a broad range of information-intensive industries and the strategic options of the incumbent firms in the respective traditional industries in response to this radical change. Its purpose is to provide explanations of why and how radical innovators are able to redefine the rules of the market leading to economic growth and development.
\end{abstract}

Keywords: creative destruction, prosumer, monetize, incumbents, institutionalization

\section{Introduction}

Creative destruction is an economic theory of innovation and progress introduced by German sociologist Sombart (2006) and developed and popularised by the Austrian economist Schumpeter. Schumpeter (1975) used the term to describe the process of transformation that accompanies radical innovation, and according to Schumpeter's vision, innovative market entry by entrepreneurs was the driving force of sustained long-term economic growth. In Schumpeter's view, this also destroyed the value of established companies that enjoyed some degree of monopoly power.

Three entrepreneurs, Larry Page and Sergey Brin (the co-founders of Google) and Steve Jobs (co-founder and CEO of Apple) are currently in the process of revolutionising the economic structures of many industries and creating new markets and organisational business models in a gale of creative destruction reminiscent of

Nigel Walton, MBA, Dip. M., BA (Hons), Worcester Business School, University of Worcester.

Klaus Oestreicher, Ph.D., Worcester Business school, University of Worcester.

Correspondence concerning this article should be addressed to Nigel Walton, University of Worcester, City Campus, Castle St., Worcester, WR1 3AS, UK. E-mail: n.walton@worc.ac.uk. 
the theories developed by Sombart and Schumpeter.

The development of radical innovations such as digital technology, the Internet, the search engine and the widespread diffusion of web-enabled consumer electronics devices (including PCs, laptops, mobile phones, and gaming consoles) has resulted in the erosion of traditional industry and market boundaries and the emergence of new competitive business models and strategies.

It is the purpose of this paper to analyse the impact that Google and Apple are having upon a broad range of information intensive industries and the strategic options of the incumbent firms in these traditional industries in response to such radical change.

\section{The Changing Environment and Source of Creative Destruction}

During the last 30 years, the business world has undergone enormous social, technological, economic, and political change resulting in globalisation (see Figure 2). In 1981, the United States of America officially became the world's first service economy followed by other leading G7 western countries which lost their competitive advantage - in many areas of manufacturing - to the low wage emerging economies. At the same time, the personal computer industry was starting to grow very rapidly and this was followed by the Internet, the introduction of the worldwide web (Tim Burner's Lee) and digital technology (Fahey \& Narayanan, 1986). Drucker (1988) heralded this as a new era that he named the "information age" in which modern employees had become knowledge workers. Knowledge and information had taken over from capital as the key resource and source of competitive advantage.

This change of position is also emphasized by Kotler, Jain, and Maesincee (2002), who argued that the driving factor of the so-called new economy was the customer which was in contrast to the old economy still believing in the dominance of capital (see Figure 1).

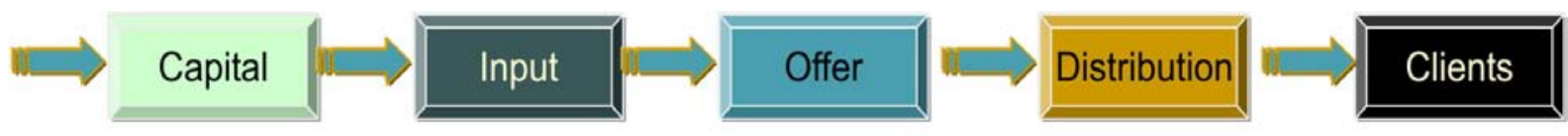

Old

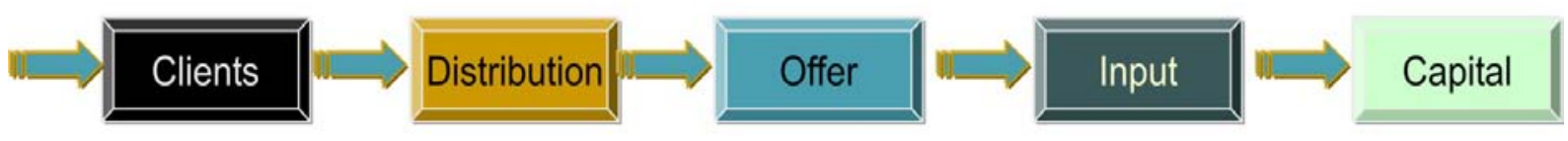

New

Figure 1. The shift from consumer to “prosumer” model (Kotler et al., 2002).

A good example of this transformation was instigated by Dell who was the first company to revolutionise how customers bought computers (Kotler et al., 2002). Customisation was facilitated by the Internet in the form of which put the customer at the centre of the organisational activities. One result of this shift was the emergence of the prosumer concept, which reduced the ways in which established firms could follow a business model, in which a customer has to buy what they offer. The new business models follow the expectations of customers in nearly every detail and create the products that the customers want. The second consequence is that the customer has changed from being a marketing objective to its present position of being a market power (Kotler et al., 2002).

Much of Google and Apple's success may be explained in this way since it is suggested that both 
companies understand that in a cause-and-effect relationship, capital is no longer the cause but the effect of a consumer-centred business model. Microsoft has adopted a different approach and has transformed backwards. Through institutionalisation, Microsoft has placed capital back at the front of the chain (see Figure 1) based on the "old" model. This may help to explain why Microsoft has tended to buy a market share today (through acquisitions) instead of creating it.

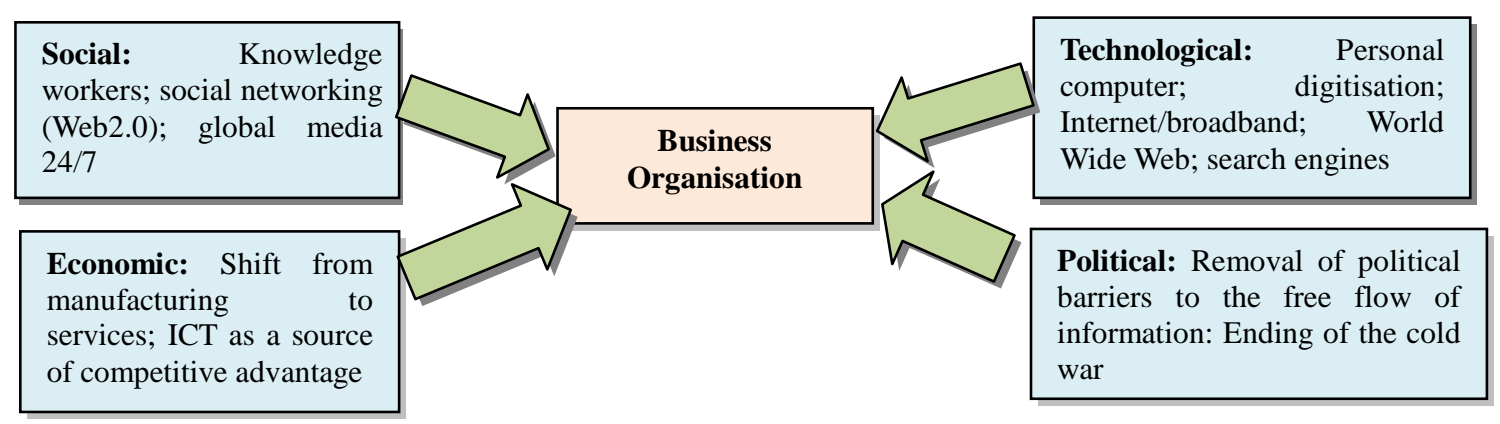

Figure 2. STEP Model (Fahey \& Narayanan, 1988).

This proliferation of new services meant that the transformation processes of organisations were also changing. In the former capitalist manufacturing environment, manufacturing firms would input raw materials, process them and output a finished product. However, in the post-capitalist information age, one of the primary processing activities of organisations is now information and customers not simply materials (Slack et al., 2007).

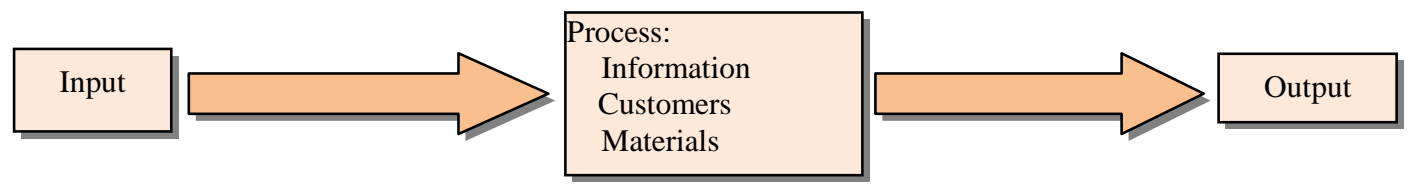

Figure 3. Transformation process model (Slack et al., 2007).

As the move towards knowledge/information-based service, industries accelerated (supported by digital technology, high personal computer ownership, and broadband take-up) two important developments occurred. First, the emergence of Napster (1999-2001) and the concept of file sharing and the commercialisation of search-engine companies in the 1990s_culminating in the launch of Google in 1998.

The model above (as shows in Figure 3) is a line of sequential order, which is known as ITO-strategy (Input-Throughput-Output). The importance of this conceptualisation is that organisational activities follow a strategic direction, which is superior to tactical manoeuvres and operational activism. Google is understood to have followed this ITO-strategy (whether this was implicit or explicit is of secondary importance) since this has resulted in a fundamentally new way of creating sustainable customer satisfaction. In an understanding of Abernathy, Clark, and Kantrow's $(1983,1984)$ taxonomy of innovation, presented in the transilience map, their search engine was initially a revolutionary innovation but had, by its consumer-focused orientation, the power to transform itself to the highest degree of architectural innovation. Innovation forces, technology, and market linkages are therefore fully addressed (Abernathy et al., 1983, 1984).

Steve Jobs (co-founder of Apple) was quick to see the potential to monetise what was an illegal service being provided by Napster which resulted in a stream of new blockbuster products including iTunes, iPod, iPhone, and iPad. 
Larry Page and Sergey Brin's innovation was incremental in that Google's search engine technology was at least $20 \%$ better than their competitors in that it was faster and produced better quality results (van Veelen, 2003). However, it was in the area of marketing innovation where Google's competitive advantage would be achieved. The decision to provide free search and use advertising revenues as their primary income stream was to have a dramatic impact on Google's future development path and the fortunes of what would later appear to be adjacent industries. Google's strategy of generating income from advertising relied on their ability to attract a large amount of "traffic" into their website. The strategy that Google has adopted to achieve this goal is what has been the major cause for concern to companies in what would traditionally have been considered to be unrelated industries and markets. These include books, software, browsers, videos, news and sport content and recently travel.

Finally, Napster demonstration that there was a market for downloadable music, and other forms of media content was now being exploited and monetised by Apple further consolidating the company's competitive advantage. In this context, light should also be shed in the fact that the real success was created by the iPad and by the revolutionary concept of combining (again) technology—-the iPad—with market linkages—iTunes (Oestreicher, 2011).

\section{The Impact of Google \& Apple’s Strategies on Other Industries and Markets}

Google currently provides a broad range of free products from its search engine website including books, software, browsers, and videos. This is having an impact on a broad range of industries including publishing, music, computing, and mobile phones. Although Apple monetises the downloadable concept invented by Shawn Fanning of Napster by charging a fee for its product/service, this is seriously impacting upon the revenue-generating potential and profitability of the music industry. The result for this industry is that it finds itself in a fast declining environment, which threatens its existence in its present form and structure. Moreover, in contrast to Google and Apple's business models, a major reason is seen in the difference between an institution-centred and a consumer-centred business model (Oestreicher, Kuzma, \& Walton, 2011).

In fact, both Google and Apple and a broad range of technology companies (e.g., eBay, Amazon, Facebook, and YouTube) have the potential to disrupt and even destroy the competitive dynamics of a broad range of industries. Any industry/market where customers require an information/knowledge based on products or service which can be delivered using a virtual platform are potentially under threat. This argument is supported by Moore's (2006) typology, in which platform innovation plays an important role in the modern, innovation-driven economy.

When Schumpeter (1975) elaborated and popularised Sombart's original theories, he identified five types of innovation, namely:

- new products or service;

- new methods of production (process innovation);

- developing new markets;

- identifying new sources of supply;

- new forms of organisation.

If we take the Google business model as an example, Google is now capable of achieving all five types of innovation identified by Schumpeter: It is providing new products and services in digital formats, and it is 
changing business processes by providing a downloadable solution based on cloud computing concepts; it is developing new markets; it has become a new source of supply and this is resulting in new forms of organisation i.e., the virtual company not bricks and mortar. Returning to Abernathy et al.'s $(1983,1984)$ transilience map, this form of innovation represents architectural innovation again.

Most companies can usually respond to innovation in the form of new products and services. However, when the innovation also destroys core resources and capabilities, traditional industry boundaries and even an entire business model then an effective strategic response becomes extremely difficult.

The opening up of new markets... illustrate the process of industrial mutation that incessantly revolutionises the economic structure from within, incessantly destroying the old one, incessantly creating a new one... The process must be seen in its role in the perennial gale of creative destruction; it cannot be understood on the hypothesis that there is a perennial lull. (Schumpeter, 1975, p. 82)

\section{Joseph Schumpeter, the Process of Creative Destruction, 1942}

The next stage of our analysis is to clarify what we mean by the term "industry". Economists define industry as a group of firms that supplies a market (Grant, 2008). This means that a close correspondence exists between markets and industries. However, this raises the question of what is the difference between analysing industry structure and analysing market structure. The main difference is that industry analysis is concerned with industry profitability (Porter's five forces model, 1985). This looks at industry profitability being determined by competition in two markets: product markets and input markets.

A market's boundaries are defined by substitutability. There are two dimensions to this substitutability on both the demand-side and the supply-side. Napster demonstrated that on the demand-side consumers were more than happy to substitute paid hard disc content for free downloadable music (file sharing). However, the music industry did not respond to this threat by substituting their existing product with a revenue earning downloadable alternative. In other words, by the institutional understanding of business, the new P2P-driven ways of consumption contradicted the established business model of this industry, since it threatens control and collaboration with the distribution chain and the autonomy of this industry, and it is against all the established resources, processes, and values that the music industry owns (Oestreicher, 2011; Oestreicher et al., 2011; Christensen, Anthony, \& Roth, 2004). It took the vision of an entrepreneur (Steve Jobs) from a seemingly unrelated industry (computers) to see the market potential for monetising the downloadable concept.

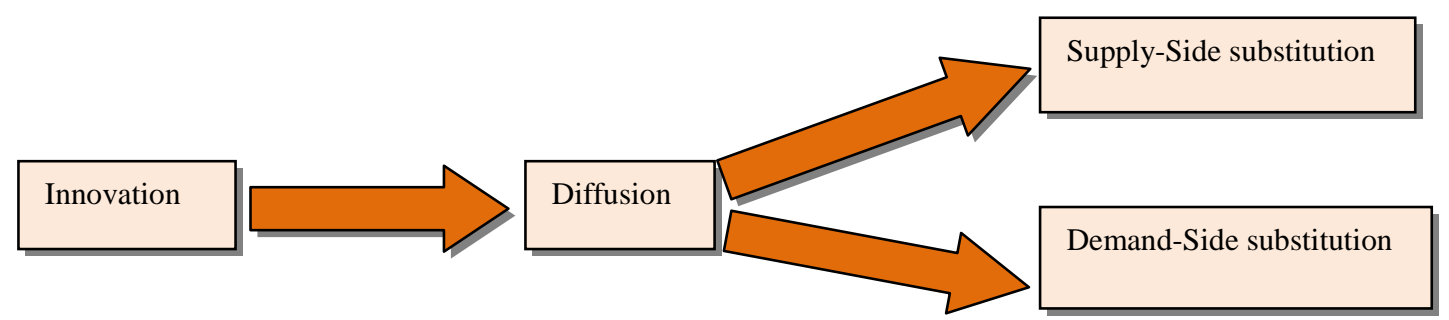

Figure 4. Innovation process model (Grant, 2008).

In the case of Google, the move towards substitution has also been very significant. Consumers have demonstrated high levels of demand-side substitution in electronic books, mobile phone operating systems software, computer browsers and software, and videos. On the supply-side, book publishers, software vendors, telecommunications companies, and film studios, have not been in a position to provide a substitute product because of the free nature of Google's unique selling proposition (USP). This has resulted in these industries 
becoming unattractive as well as threatening the very existence of many firms. The disintermediation of product/service delivery has also had a major impact on the structures of these industries and the recent decline in the fortunes of HMV and Waterstones bears testimony to this.

Not only are the incumbents of these traditional industries being threatened by the new product/services and processes offered by downloadable suppliers, but they have not been able to adopt the paradigm and positioning strategies of the new product/service providers as a younger generation of consumers opt for cloud-based products and services from high profile global brands such as Google and Apple (see Figure 5).

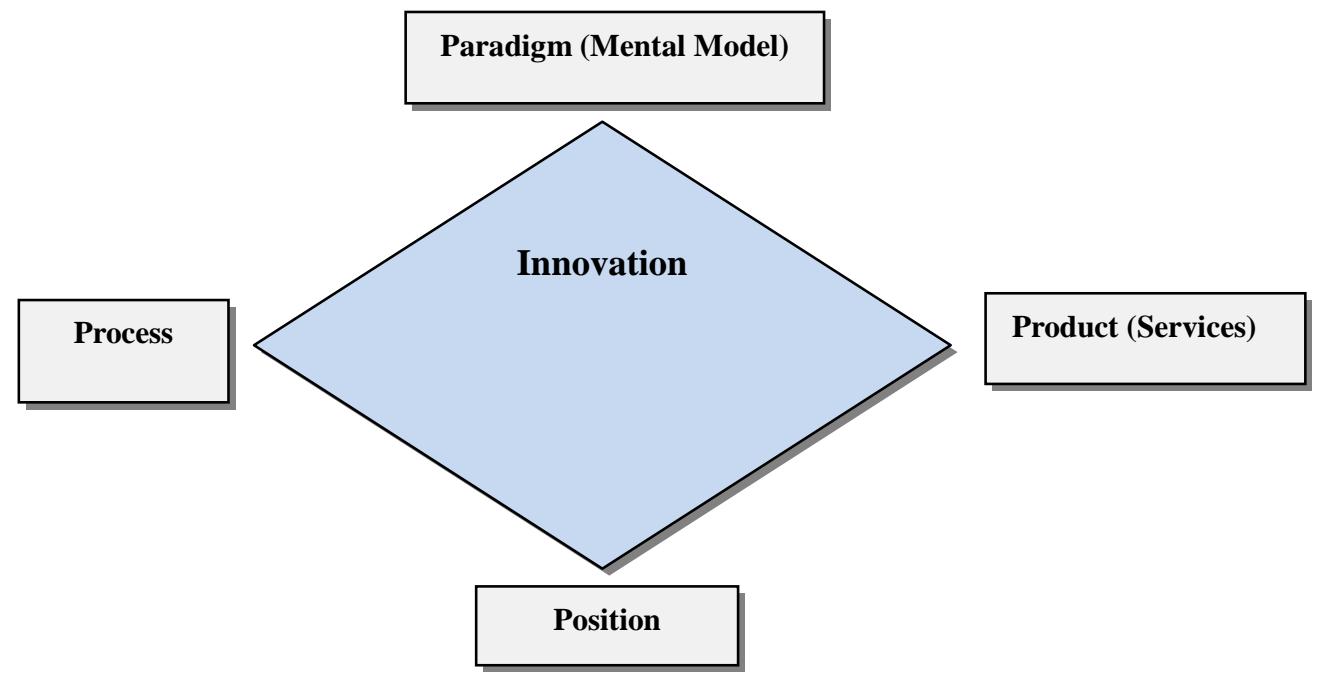

Figure 5. The innovation diamond/4Ps of innovation space (Tidd \& Bessant, 2009).

In addition, the delineation of market and industry boundaries based on physical geography is also being destroyed due to the worldwide web and the diffusion of broadband and web-enabled mobile consumer electronic devices on a global scale. This process is permanently accelerated by facilitating technologies following the concept of convergent technologies of which smartphones are just one device. It should also not be forgotten that the new "Internet2" will revolutionise the whole industrial structures in ways which cannot be predicted. For example, its petabyte-based power will allow data transfers of GB in seconds.

Schumpeter's theories are endorsed by Costas and Geroski (2004) who categorised innovation in two dimensions: (1) changes in consumer buying behavior; and (2) the effects on the competencies of established incumbent organizations. Therefore, both Schumpeter's (1942) and Costas and Geroski's (2004) models illustrate that radical innovation has a high impact upon existing industries/markets and consumer habits (see Figure 6).

Aboulnasr, Narasimhan, Blair, and Chandy (2008) also argued that radical innovations (in this case digitisation) were often the agents of creative destruction and threaten to destroy existing market positions but often yield new marketing opportunities (electronic downloadable alternatives). Therefore radical technological innovations create new market opportunities whilst simultaneously destroying or transforming demand in many existing marketplaces. The key process of creative destruction is the re-combination of existing assets and resources in order to develop and commercialise innovations. Subsequently, Christensen (1997) and Hill and Rothaemel (2003) referred to this as disruptive technological innovation because of its destructive effects on existing markets. 


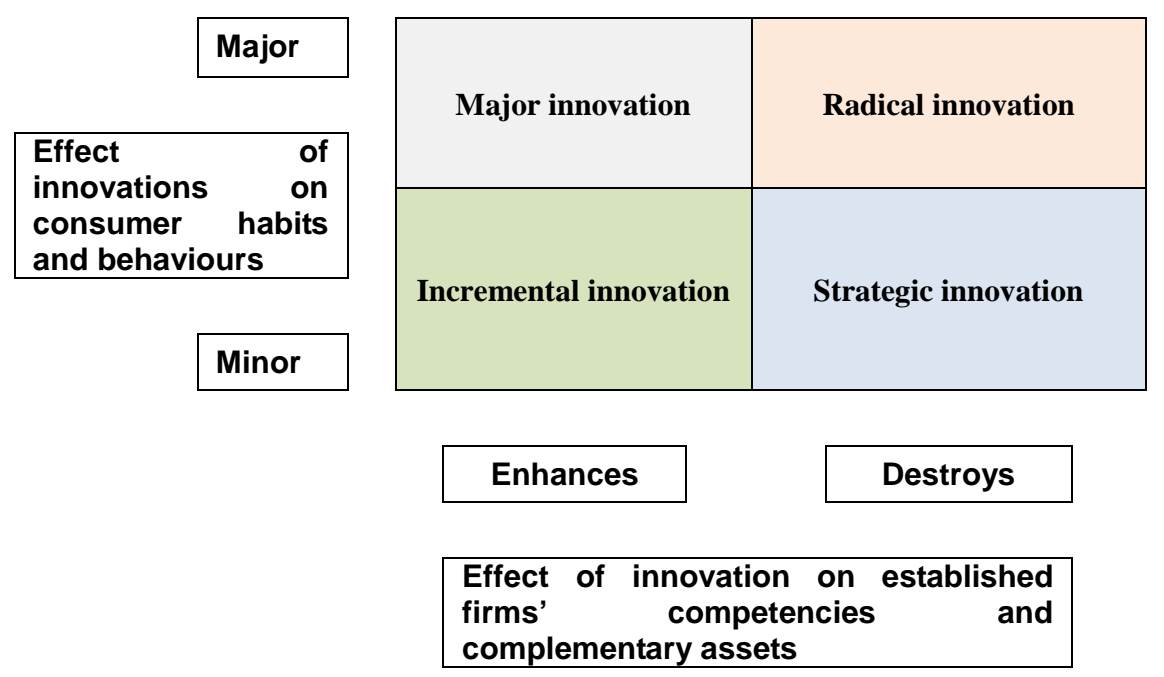

Figure 6. Costas and Geroski's innovation model (2004).

Hill and Rothaemel (2003) found that a persistent theme within incumbent enterprises was that they have great difficulty in innovating radically new technologies and thus went into decline whilst simultaneously new entrants (in this case from seemingly unrelated industries) rise to market dominance by generating (or exploiting) radical new technology. According to Gilbert and Neuberg (1984), incumbent organisations have a disincentive to produce radical innovations compared with new entrants for fear of destroying or altering existing industries (cannibalisation) to which their products have traditionally enjoyed success. Paradoxically, mechanisms that help ensure organisational survival in stable environments contribute to inertia and organisational decline when confronted with radical change (Hill \& Rothaemel, 2003). Leonard-Barton's (1992) qualitative study echoes Hill's suggestions and finds that the core competencies of an organisation can become core "rigidities" that can limit an organisation's ability to adapt to a changed environment.

This argument is supported by Redding (2002), who saw a strong connection and interaction between innovation and path-dependency, which leads in his opinion, to a lock-in by technology. The path-dependent orientation on resources, processes, and values creates an organizational context, which makes it difficult for organisations to think in new and different ways, especially when an environment becomes increasingly hostile by the emergence of new technologies and/or business models. Oestreicher (2011) has extended this technological lock-in and connected it to organisational core activities, especially when the prior environment allowed a high level of control (compared with Microsoft's position). The focus on maintaining the status quo can become a high burden and prevent organisations from renewal, which adapts them to the changing environment and creates high risks of obsolescence. Oestreicher (2011) argued that a close relationship between institutionalization (expressed by control and a status quo orientation) and the resulting resource allocation cannot be excluded. This is not only aligning this context to the institutional school of thought, but is also challenging the resource-based view. Finally, it also contradicts the determinants which Johnson, Scholes, and Whittington (2011) saw as important parameters for organisational success. Each organisation serves a market purpose (Baker, 2007) but only when the market accepts its offers.

Another explanation linked to incumbent inflexibility is embedded within the organisation's value network. Christensen (1997) attributed this to an organisation paying too much attention to satisfying the demands of and cooperating with various constituents of the value network (suppliers, customers, product providers etc.), which 
may have served them well in the past. However, when faced with disruptive innovative change, the commitment to this network may produce further inflexibility. Pfeffer and Salancik (1978) attributed this to resource dependence theory, which suggests that an organisation's strategies are constrained by external forces that are the critical resources to an organisation (customers, suppliers etc.). Subsequently, an organisation's internal priorities are to maximise quality through existing resources. When a disruptive technology invades an existing market incumbent, firms struggle to adapt, due to rigidness and inertia created by the value network around the incumbents legacy technology. Moreover, the impact of digitization on the reconfiguration of the value network such as the disintermediation of the value chain has been most noticeable in recent years. Leon-Sceti complains that the music industry today is much closer to an environment in which it can extract one Euro out of a million consumers rather than 10 Euros out of a thousand (Oestreicher, 2011).

\section{The Competitive Response}

The provision of free products and services by Google and more convenient methods of supply by Apple are a serious competitive threat to many traditional firms and industries which have now become unattractive. The strategic options that open to many of these firms are limited to harvesting strategies, moving into higher value niche' segments, exiting in the respective industry or market or seeking legal redress where possible (Harrigan, 1988). None of these strategies are likely to provide a sustainable solution to the problems of declining market share and profits and ultimately survival. According to Peter (2001), "companies cannot shrink their way to greatness".

\begin{tabular}{|c|c|}
\hline Leadership & Harvest or Niche' \\
\hline Harvest of Niche' & Quick Sale/Liquidation \\
\hline
\end{tabular}

Figure 7. End game strategies (Harrigan, 1988).

Adner and Snow (2010) also highlighted two potential macro-level strategic reactions to the introduction of a disruptive technology: (1) Racing strategies, by which an organisation attempts to increase the performance of their existing technologies/business models in order to reduce the disparity created by diffusion of the new technology; and (2) Retreat strategies, by which organisations accommodate the entry of a new innovation by repositioning their existing products within new markets. Howell (2002) presented a much broader categorisation, suggesting four strategic decision variables that an organisation can adopt when facing disruptive innovation.

- Initially exit from the old market, which is the most drastic form of action. However, in some instances this is the most appropriate, if the new technology has caused significant shrinking of the existing market. Otherwise this strategy may indicate disinterest (or incapability) of the firm to face competition under new market conditions (Schiavone, Simone, \& Quintano, 2011). This strategy also implies that an organisation must seek new markets to which can invest its resources.

- The second option is for an organisation to adopt the new technology. Howell (2002) suggested firms should reorganise their portfolios by developing new products that incorporate the new technologies and the new paradigm. Schiavone et al. (2011) suggested that this method means that the changing organisation actually contributes to destruction of the former market equilibrium. Afuah and Utterback (1994) suggested this strategy was difficult to implement, even for larger organisations with large resources. 
- The sailing ship effect is the acceleration of innovation in the old technology in response to the threat from new technology (Howell, 2002). This occurs when organisations attempt to preserve their own technological competencies from decline in the face of disruptive technologies. They may do so by repositioning their products within niche markets. Snow and Skaggs (2004) provided three possible explanations for this: initially old technologies are improved to avoid being replaced by the new ones; secondly, incumbent technologies efficiency can improve without technological change or replacement; and thirdly, the substituting technology can generate notoriety for the old technology from different uses rather than from the new technological innovation.

- Aboulnasr et al. (2008) also carried out research into organisational responses to innovation which emphasised the need to examine markets dynamically and not just consider how they are today but how they could be tomorrow. This is based upon how radical innovations can cause previously small markets to explode in size.

In order to evaluate the theoretical options explained above, it is important to look in some detail at the markets and companies that are directly affected by the strategies of Google and Apple. First, we will look at Google's impact. Google's business model is based on attracting large amounts of traffic via its search engine browser in order to maximise advertising revenues which is its primary source of income. In order to do this, it has developed a broad range of mainly free products ranging from electronic books, software, browsers, media content and more recently, holiday and airline bookings.

Google were one of the pioneers when they began building a digital repository of free downloadable books on their website over eight years ago. This accelerated a trend towards the digital provision of books with Amazon providing electronic copies and e-readers such as the Kindle. According to Sachs (2011), people are not reading less than previously, but they are now buying fewer traditional hardback copies. Figures from the Association of American Publishers (AAP) reveal the following compound growth rate of e-books in the 2004-2010:

- 2004: +169.5\%;

- 2005: +53.1\%;

- 2006: $+44.8 \%$;

- 2007: $+24.1 \%$;

- 2008: +23.6\%;

- 2009: +68.4\%;

- 2010: $+127.6 \%$.

Figures released in early April 2011 revealed that eBooks have become the single bestselling category in American publishing for the first time. The report from the Association of American Publishers also said that eBook sales in February were $\$ 90.3$ million, making digital book the largest single format in the U.S. for the first time. America's eBooks enjoyed a 202.3 percent growth in sales in February (2011) compared with the same time last year.

E-retailer giant Amazon had already announced in January that its sales of Kindle e-books were outpacing paperback sales. For every 100 paperbacks sold in 2010, Amazon says it sold 115 Kindle e-books. Last summer, Amazon announced that e-book sales had surpassed those of hard covers.

The bad news for publishers is that although e-book sales have increased by $169.4 \%$ since the beginning of 2011 , overall categories of print trade books showed a decline of $24.8 \%$, and the decline in print sales to $\$ 215.3$ 
million is not compensated for by the increase in e-book sales. Earlier this year, several major publishers confirmed that e-books had increased to about 10 percent of their total sales. Some publishing experts now predict that within the next two to three years e-book sales will comprise up to 25 percent of all book sales.

This growth of e-book sales has impacted on both the book publishers and the intermediaries. Many of the large publishing houses in the USA have been forced to downsize in response to the declining sales whilst book resellers having to adopt niche' marketing strategies focusing on specialist publications and authors. Even the forte' of the traditional book reseller, book signing, has now been usurped with the arrival of a smart phone app. which allows a book author to sign an e-reader remotely.

Google's decision to provide web browsers and open source software technologies have also impacted on the business models of companies in other markets. The high adoption of Google's Android operating system in mobile phones has accelerated the growth of smart phone ownership. According to Gartner research (McDermott, 2011, p. 16) “... by the end of next year, Android will account for almost half of the world's smart phone market”. This has had a significant impact on Nokia, the market leader of mobile phones which has been forced to form an alliance with Microsoft to access new operating systems technology and as smart phones overtake conventional handsets which seriously undermines Nokia's future competitiveness. The availability of open source software via cloud computing and the availability of Google's Chrome browser has forced market leader Microsoft into a strategic alliance with Yahoo, so as to gain a market presence in the Cloud computing market, because Google is undermining its traditional business model based on bundling pre-installed software with existing hardware. Google have therefore accelerated the development of cloud computing as a new market segment with the potential for huge growth (Aboulnasr, 2008).

Google’s most recent diversification involves the acquisition of ITA software for \$700 million. This will place Google in a leading position in the travel search and online bookings market. Any disintermediation that has not already occurred in terms of the travel agency market is therefore likely to be rapidly accelerated.

Apple has also had a major impact on the business models of markets outside their original industry. Apple's primary impact has been on the music/entertainment industry due to the introduction of iPod, iTunes, iPhone, and iPad range of products. Steve Jobs' decision to monetise Fawn Shanning's (Napster) file sharing technology has decimated the sales volumes of both CDs/DVDs and the Blue-Ray DVD player. Video sales have also followed a similar trajectory.

A recent In-Stat report (2010) revealed that the importance of DVDs to the entertainment industry will decline significantly over the next few years. Physical disc sales, which include both DVDs and Blu-ray discs, are expected to decline by $\$ 4.6$ billion between 2009 and 2014. In-Stat said that over that period, DVD sales were expected to plummet. At the same time, Blu-ray sales were expected to climb but not enough to make up for the decline in DVDs. In place of physical discs, streaming content and digital downloads were quickly gaining steam. Research by Oestreicher (2011) has produced evidence of some significant developments which are supported by a number of interviews in the industry. For example:

- The new Blu-ray disc format will be the last physical format of the home entertainment industry;

- It will only achieve $40 \%$ of the total DVD market;

- The remaining life cycle for physical products will be a maximum of three to five years;

- Most customers are satisfied with the performance of standard DVD and even the new 3-D format is expected to change little;

- The already fully developed new format of Holographic Versatile Discs (HVD), with a capacity of one 
terabyte, are unlikely to achieve more than a niche position in data security and will only be used by customers who do not trust cloud computing;

- Finally the present industry structure of those manufacturers of the physical product of optical discs is expected to become obsolete.

In-Stat said that the video-download and streaming revenue was expected to grow from the $\$ 2.3$ billion it generates now to $\$ 6.3$ billion "within five years".

"Video disc rentals will continue their significant decline”, In-Stat principal analyst said that.

Keith Nissen said in a statement that "The convenience and utility of the online offerings are simply too compelling”.

In-Stat also examined the impact that streaming could have on the television business (both Apple and Google's new areas of market development). According to the research firm, download revenue of U.S. television programming is expected to "more than triple" between 2010 and 2014. Moreover, the company said that video-on-demand subscription revenue could hit \$3.5 billion by 2014 .

A summary of the range of markets and companies that have been (or soon will be) affected by Google and Apple's creative destruction is quite extensive and includes:

- Book publishers and resellers;

- Music companies (labels) and resellers;

- DVD hardware manufacturer's video rental chains;

- Computer software and hardware providers;

- Mobile phone software and hardware providers;

- Airlines and travel agents.

This excludes other developments by both companies including TV as well as mobile phone applications which will have significant implications for other markets.

The ability of incumbents in traditional markets to respond to these competitive threats is extremely limited. Both Apple and Google were early adopters (see Figure 8, diffusion of innovation model) of the new digital technologies and were therefore able to gain a significant lead-time advantage in building high levels of customer loyalty amongst a huge customer base. In terms of Porter's five forces framework, Google and Apple have built up high barriers to entry, so competitors are not able to retaliate due to the high capital costs of the technology (during the early years of development) and the absence of appropriate resources and competencies. Only Microsoft with its huge cash surplus has been able to mount a defence in the computer software and mobile phone markets but these strategies lack significant impact. Google and Apple have also entered these markets as substitutes using shielding strategies (Hamel \& Prahalad, 1993) which the industry incumbents failed comprehend until it was too late. Once access to these markets had been established, the rules of the game were changed and traditional business models were soon replaced with new positioning strategies and paradigms as illustrated in Tidd and Bessant's (2008) 4Ps of innovation space (see Figure 5). Google and Apple were able to innovate on all four dimensions of the model including new products/services that were delivered using new processes.

If we consider Harrigan's (1988) end game strategies model, the prospects of incumbents taking a leadership position are unlikely due to the inertia displayed by the organisations concerned. The weaker companies may eventually seek a quick sale or liquidation. Blockbuster and Borders have already followed this 
route whilst HMV appears to be pursuing a Harvester/Niche' strategy and is undertaking a store closure programme, but it is also diversifying away from CDs and DVDs into home electrical goods as part of its repositioning strategy (Wembridge \& Barrett, p. 17). This also complies with Adner and Snow's (2010) retreat strategy. However, there does not appear to be any evidence of Adner and Snow's racing strategies.

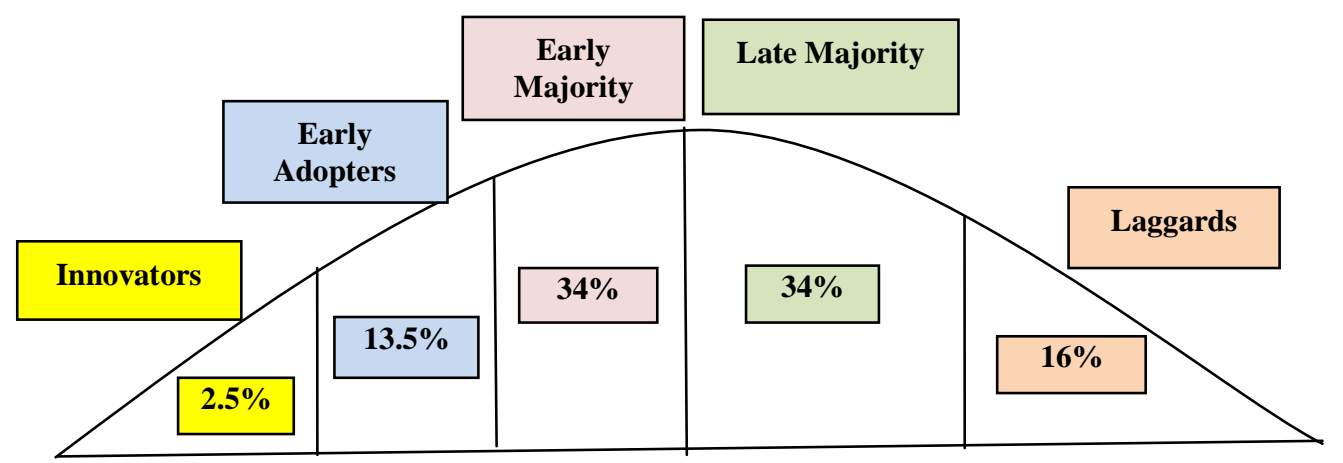

Figure 8. Diffusion of innovation model (Rogers, 1983).

If we look at Howell's (2002) framework, a sailing ship strategy would appear to be commonplace in terms of the music companies and book publishers. Exit strategies, although not deliberately planned (Mintzberg \& Waters, 1985) appear to be emerging in response to rapid declines in market share in some markets, i.e., travel agents. However, Microsoft would appear to be pursuing Howell's (2002) strategy of adopting new technologies through the acquisition and rapid organic growth of new businesses. For example, Microsoft's heavy investment in the Yahoo alliance to create a greater search engine presence to combat the threat of downloadable software via the Internet is a good example of this. Microsoft has also moved aggressively into cloud computing with a widespread corporate business-to-business programme to sell the open source concept to new customers. Its recent acquisition of Skype has also been executed because of the need to build an increasing Internet presence.

Howells's (2002) technology adoption strategy would also appear to be relevant to the mobile phone and computer market where incumbents are copying new technologies and forming alliances to access new competencies, resources, and know-how.

As Google and Apple grow in terms of market power, this raises the question of competitor retaliation through the lobbying of government to implement some form of anti-trust legislation. However, since the Internet is not owned by any single organisation and cannot be regulated, the prospects of such actions are unlikely. So what would normally have been a source of retaliation by incumbent firms cannot be deployed due to the virtual nature of the competitive threat. Although the Internet began as an egalitarian platform for the sharing of information, it would appear that an oligopoly of powerful Internet firms and Internet-enabled firms such as Apple are now becoming established in cyberspace (Google, eBay, Amazon, Facebook, YouTube, Yahoo/Microsoft MSN etc.) who are now capable of entering information/knowledge-based industries and appropriating high economic rents for their own businesses at the expense of traditional incumbents whilst simultaneously changing the competitive dynamics and structures of these industries. By leveraging their existing technologies and customers, these corporations have already shown how they can reshape the traditional bricks-and-mortar landscape. 


\section{References}

Abernathy, W. J., Clark, B. K., \& Kantrow, A. M. (1983). Industrial renaissance: Producing a competitive future for America. New York: Basic Books Inc..

Abernathy, W. J., Clark, B. K., \& Kantrow, A. M. (1984). Innovation: Mapping the winds of creative destruction. Retrieved $\begin{array}{llll}\text { March 21, 2008, from } & \text { 21, }\end{array}$ http://www.sciencedirect.com/science/article/B6V77-45MFSH5-H/2/5749c2d936bb6068f10dc1263ce8cf92

Aboulnasr, K., Narasimhan, O., Blair, E., \& Chandy, R. (2008). Competitive response to radical product innovations. Journal of Marketing, 72(3), 94-110.

Adner, R., \& Snow, D. C. (2010). Bold retreat: A new strategy for old technologies. Harvard Business Review, 88(92), 76-81.

Afuah, A. N., \& Utterback, J. M. (1994). Responding to structural industry changes: A technological evolution perspective. Industrial and Corporate Change, 6(1), 183-202.

Association of American Publishers. (2011). Popularity of books in digital platforms continues to grow. AAP Publishers February 2011 Sales Report.

Baker, M. J. (2007). Marketing strategy \& management (4th ed.). Basingstoke: Palgrave Macmillan.

Christensen, C. M. (1997). The innovator's dilemma: When new technologies cause great firm's to fail. Boston: Harvard Business School Press.

Christensen, C. M., Anthony, S. D., \& Roth, E. A. (2004). Seeing what's next: Using the theories of innovation to predict industry change. Boston: Harvard Business School Press.

Costas, M., \& Geroski, P. (2004). Racing to be second. Business Strategy Review, 15(4), 25-31.

Drucker, P. F. (1988). The age of discontinuity: Guidelines to our changing society. New York: Transaction Publishers.

Drucker, P. F. (1993). Post capitalist society. New York: Harper Paperbacks.

Fahey, L., \& Narayanan, V. K. (1986). Macro-environmental analysis for strategic management. Andover: South-Western/Thomson.

Gilbert, R. J., \& Neuberg, D. M. G. (1984). Uncertain innovation and the persistence of monopoly: Comment. American Economic Review (AER), 74(1), 238-242.

Grant, R. M. (2008). Contemporary strategy analysis (6th ed.). Oxford: Blackwell Publishing.

Hamel, G., \& Prahalad, C. K. (1993). Strategy as stretch and leverage. Harvard Business Review, 71(2), 75-84.

Harrigan, K. R. (1988). Managing maturing businesses. Lexington, M.A.: Lexington Books.

Hill, C., \& Rothaemel, F. (2003). The performance of incumbent firms in the face of radical technological innovation. Academy of Management Review, 28(2), 257-274.

Howell, J. M. (2002). Champions of technological innovation: The influence of contextual knowledge, role orientation, idea generation and idea promotion on champion emergence. The Leadership Quarterly, 2004, 15, 123-143.

In-Stat. (2010). Internet-delivered video growth continues to drive physical DVDs into double-digit decline. Retrieved December 14, 2010, from http://www.instat.com

Johnson, G., Scholes, K., \& Whittington, R. (2011). Exploring corporate strategy (9th ed.). Harlow: Prentice Hall.

Kotler, P., Jain, C., \& Maesincee, S. (2002). Marketing der Zukunft: Mit Sense und Response zu mehr Wachstum und Gewinn. Frankfurt: Campus Verlag.

Leonard-Barton, D. A. (1992). Core capabilities and core rigidities. Strategic Management Journal, Summer Special Issue, 111-126.

MacVaugh, J., \& Schiavone, F. (2010). Limits to the diffusion of innovation. European Journal of Innovation Management, 13(2), 197-221.

McDermott, J. (2011, April). Apple does not crumble: Smashes street expectations. Financial Times (p. 24).

Mintzberg, H., \& Waters, J. A. (1985). Of strategies, deliberate and emergent. Strategic Management Journal, 6(3), $257-272$.

Moore, G. A. (2006). Dealing with Darwin: How great companies innovate at every phase of their evolution. New York: Portfolio.

Oestreicher, K. (2011). Réponses stratégiques des industries en déclin: L’industrie des disques optiques en face de la technologie disruptive. Paris: CEROS Research Institute, Université Paris Ouest Nanterre La Défense.

Oestreicher, K., Kuzma, J., \& Walton, N. (2011). Sailing against the wind of creative destruction: The attack of radical innovation on the home entertainment industry. Saarbrücken: Lambert Academic Publishing.

Peters, T. (2001). The circle of innovation: You cannot shrink your way to greatness. Random House. 
Pfeffer, J., \& Salancik, G. R. (1978). The external control of organisations: A resource dependence perspective. London: Pearson Education.

Porter, M. E. (1985). Competitive advantage: Creativity and sustaining superior performance. New York: Free Press.

Redding, S. (2002, November). Path dependence, endogenous innovation, and growth. International Economic Review, 43(4), 1215-1248.

Rogers, E. M. (1983). Diffusion of innovation. New York: Free Press.

Sachs, A. (2011, March). The e-book era is here: Best sellers go digital. Time (p. 21).

Schiavone, F., Simone, M., \& Quintano, M. (2011). The marketing of new technologies and innovations in Europe. Journal of Euromarketing.

Schumpeter, J. A. (1975). Capitalism, socialism and democracy. New York: Harper.

Slack et al. (2007). Operations management (5th ed.). London: FT/Prentice Hall.

Snow, C., \& Skaggs, B. (2004). The strategic signalling of capabilities by service firms in different information asymmetry environments. Strategic Organisation, 2(3), 271-291.

Sombert, W., \& Schumpeter, J. A. (2006). Creative destruction in economies. New York: Springer.

Tidd, J., \& Bessant, J. (2009). Managing innovation: Integrating technological, market and organisational change (4th ed.). Chichester: John Wiley.

van Veelen, I. (2003). Google: Behind the screen. Open University.

Wembridge, M., \& Barrett, C. (2011, March). HMV prepares for break-up to stem rising debt. Financial Times (p. 30). 